\title{
Diameter Structure, Spatial Pattern, and Management Scenarios of Acapu Trees: A Case Study
}

\author{
Deivison Venicio Souza ${ }^{1}$ (D) 0000-0002-2975-0927 \\ Linamara Smaniotto Ferrari ${ }^{2}$ (I) 0000-0002-1629-3018 \\ Vinícius Morais Coutinho ${ }^{2}$ \\ Joielan Xipaia Santos ${ }^{2}$ (D) 0000-0002-5480-4261 \\ Sylvio Péllico Netto ${ }^{3}$ \\ Carlos Roberto Sanquetta ${ }^{3}$ (D) 0000-0001-6277-6371 \\ Ana Paula Dalla Corte ${ }^{3}$ [D 0000-0001-8529-5554
}

\begin{abstract}
We investigated the spatial distribution of population data and diameter classes and modeled the diameter structure of Vouacapoua americana Aubl. (Acapu) trees in a community forest management area. A forest census of trees with diameters $\geq 33 \mathrm{~cm}$ was carried out in the 2015 Annual Production Unit (APU-2015). Ripley's univariate K function and the global Moran's index were used to describe spatial autocorrelation. Three harvest intensities (50, 70, and $80 \%$ ) were simulated for the potential trees. The Weibull (3P) function provided the best performance to describe the diameter distribution of the original tree population, as well as in the harvested 50 and $70 \%$ intensities. In general, the spatial pattern of V. americana was aggregated. However, other natural factors, as population size, dynamics, geographic distribution, should be used as indicators for forest management and conservation of the specie.
\end{abstract}

Keywords: conservation of species, dense tropical forest, Vouacapoua americana, Weibull function.

\section{INTRODUCTION AND OBJECTIVES}

Brazil stands out on the world stage for having extensive native forest areas, protecting an expressive fraction of fungi and plants (between 9.5 and 9.9\%) of the world diversity (Forzza et al., 2010). With 18,932 endemic species, Brazil also has one of the highest rates of endemism on the planet (46.2\%) (Forzza et al., 2010). Moreover, the Amazon biome has gained notoriety for harboring 13,375 documented species, of which 2,046 (15.4\%) are endemic (Forzza et al., 2012).

However, the accelerated destruction and fragmentation of habitats threatens the rich biodiversity of Brazilian plant species. In regards to the Brazilian Amazon, Martinelli \& Moraes (2013) estimated that 87 endangered species, 90 species with insufficient data, and 142 least concern species were of interest to conservation and research. Feeley \& Silman (2009) estimated that, by 2050, 5-9\% of Amazon plant species will have gone extinct and that their habitat will have been reduced by $12-24 \%$.
In the Amazon, several of the species used for commercial timber are included in the Red Book of the Brazilian Flora (Martinelli \& Moraes, 2013). For example, Vouacapoua americana Aubl. (Fabaceae), which is also known as Acapu, is categorized as endangered, since it has been reduced above $50 \%$ in abundance over the last 90 years (Martinelli \& Moraes, 2013).

In response to the publication of the Red Book of the Brazilian Flora, in which V. americana is included, the Brazilian government has established total protection of the species, which includes the prohibition on the collection, cutting, transportation, storage, handling, processing, and commercialization, among others (BRASIL, 2014). Between January 1 and February 21, 2016, the System of Commercialization and Transportation of Pará Forest Products (Pará, Brazil) issued 5300 Forest Guides (GF1) that were related to the commercialization of $190,283.3415 \mathrm{~m}^{3}$ of Vouacapoua americana wood. Before the Official National List of Endangered Flora Species (LNOEAE) was released in 2014, the consumption of Vouacapoua americana wood in that year was of 24,481.4624 $\mathrm{m}^{3}$. However, this consumption (January and

${ }^{1}$ Universidade Federal do Pará (UFPA), Faculdade de Engenharia Florestal, Altamira, PA, Brasil

${ }^{2}$ Universidade Federal do Paraná (UFPR), Programa de Pós-Graduação em Engenharia Florestal, Curitiba, PR, Brasil

${ }^{3}$ Universidade Federal do Paraná (UFPR), Departamento de Ciências Florestais, Curitiba, PR, Brasil 
February only) decrease by 68.71 and $97.33 \%$ in 2015 and 2016, respectively, and the average value of Vouacapoua americana wood increased, reaching R $\$ 207.00$ in 2016 (SEMAS, 2016).

Owing to the endangered status of Vouacapoua americana, Martinelli \& Moraes (2013) noted the necessity of population and genetic studies. Indeed, knowledge of the spatial distribution and diameter structure of forest species is valuable for species management and conservation, including the establishment of Minimum Cutting Diameter (MCD).

Understanding the spatial distribution of key species is crucial to elucidating species' use of available resources, relative dependence those resources, and role of resources in species' establishment and reproduction (Condit et al., 2000). The spatial pattern in tropical forests is even more relevant since high diversity is closely related to population density and, therefore, with the proximity of individuals (John et al., 2002).

The purpose of the paper was to conduct a case study to describe the spatial distribution of Vouacapoua americana diameter classes using Ripley's univariate K function, to evaluate the species' original diameter structure using probability density functions (PDFs). Furthermore, the aim was to simulate scenarios with different cutting intensities for the species, in accordance with the current forest legislation and the established technical criteria. The main hypothesis of this study was that the Voucapoua americana could be managed according to maintenance criteria, with a low impact on the remaining of the diametric structure, depending on the exploration intensity.

\section{MATERIALS AND METHODS}

\subsection{Study area and data set}

The study was carried out at the Virola-Jatoba Sustainable Development Project (SDP), which is located at Belo Monte Glebe, in the northern area of the city of Anapu, Pará, Brazil $\left(51^{\circ} 17^{\prime} 55.60^{\prime \prime} \mathrm{W}\right.$ and $\left.3^{\circ} 10^{\prime} 5.90^{\prime \prime} \mathrm{S}\right)$, and encompasses an area of 37,000 ha, where 352 families have settled (Porro et al., 2015).

Data were obtained from a census of 2,400 V. americana specimens with diameter at breast height (i.e., $1.30 \mathrm{~m}$; DBH) of $\geq 33 \mathrm{~cm}$. The census had been performed in the 2015 Annual Production Unit $^{1}$ (APU-2015), which has a total area of 545.27 ha and is subdivided into six forest management units ${ }^{2}$ (FMUs; Figure 1). Through microzoning, the APU-2015 was also separated into the following zones: i) Actual Harvest Area (AHA)33; ii) Anthropized Areas (AA); and (iii) Permanent Preservation Areas (PPA; Table S1).

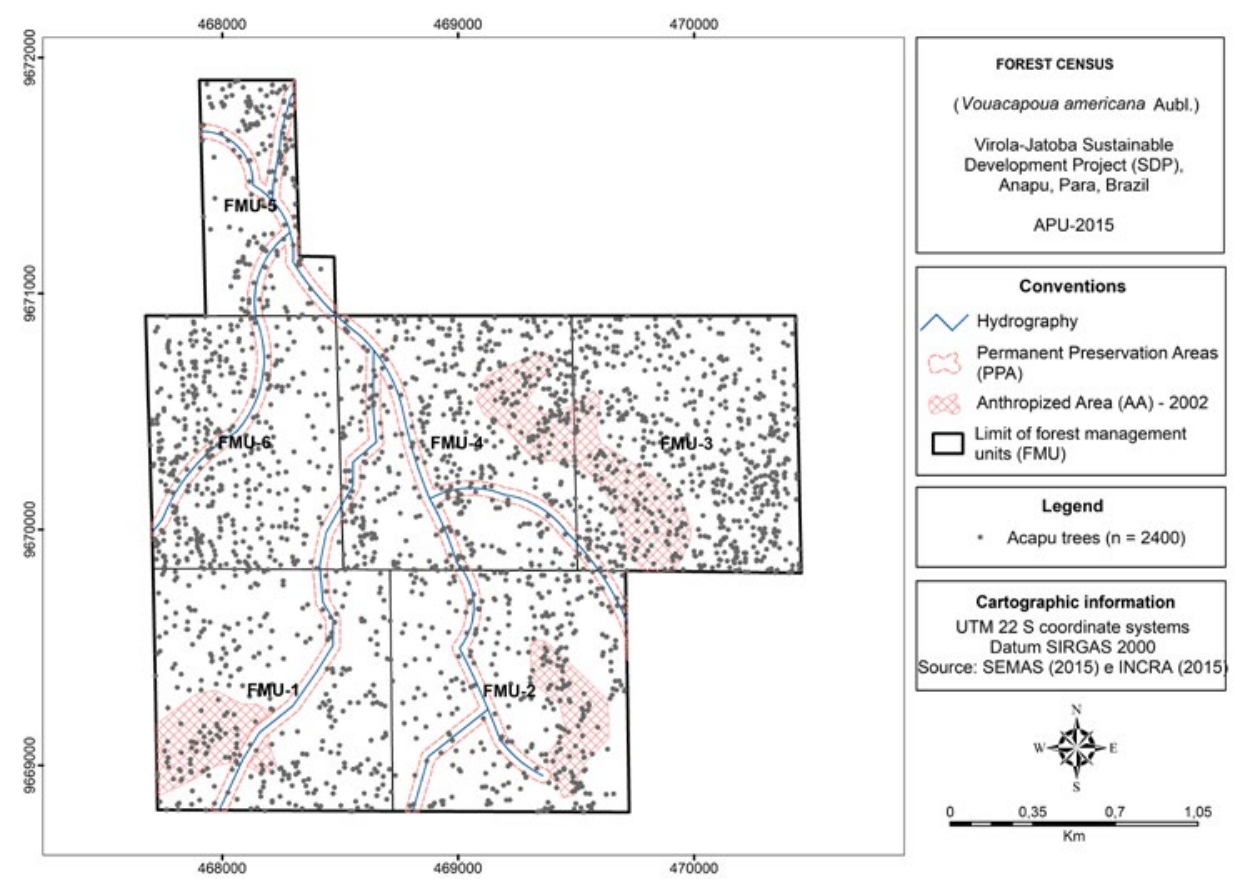

Figure 1. Spatial distribution of Vouacapoua americana trees $(\mathrm{DBH} \geq 33 \mathrm{~cm})$ in the 2015 Annual Production Unit of Anapu, Pará, Brazil.

1 Annual Production Unit (APU): subdivision of the Forest Management Area (FMA) or its Forest Management Units (FMUs), destined for exploration in one year.

2 Forest management units (FMU): operational subdivision of the Annual Production Unit (APU).

3 Actual harvest area (AHA) in the effort unit (FMU): area with trees without commercial size for harvest, excluding areas of permanent preservation, inaccessible areas, infrastructure and anthropized areas, under fallow or not, and legally unavailable areas. 
The exploitation of the APU-2015 was approved by Forest Cut Authorization No. 272790/2015, which was granted to the Virola-Jatoba Association, a part of the Sustainable Development Project of Anapu. The permit allowed 24 species to be harvested, and a total of 11.642 individuals (26.4077 $\left.\mathrm{m}^{3} \cdot \mathrm{ha}^{-1}\right)$ were removed, of which $2137\left(4476 \mathrm{~m}^{3}\right)$ were cut in a 440.8733-ha Area of Effective Management ${ }^{4}$ (AEM).

The permit prohibited the extraction (i.e., harvest) of $V$. americana trees from the Sustainable Forest Management Plan (SFMP) area or from the 2015 Annual Operational Plan (AOP), in compliance with current legislation, in particular, MMA Ordinance No. 443, which was issued on December 17, 2014. Details of Forest Cut Authorization No. 272790/2015 are available in the Integrated System of Monitoring and Environmental Licensing - Public Module (Public SIMLAM) on the Pará State Department of Environment and Sustainability website (https://www.semas.pa.gov.br/).

\subsection{Exploratory analysis and Probability Density Functions (PDFs)}

Initially, we performed an exploratory analysis of the data by calculating the measures of central tendency, dispersion, and shape to the continuous variables (diameter and volume) to each annual production and work unit. The diameter structure of $V$. americana trees was studied in the APU-2015 and its working units using frequency histograms with a class amplitude of 10 $\mathrm{cm}$ of DBH $(\mathrm{C} 1: \mathrm{DBH}=30+40 \mathrm{~cm} ; \mathrm{C} 2: \mathrm{DBH}=40+50 \mathrm{~cm}$; C3: $\mathrm{DBH}=50+60 \mathrm{~cm} ; \mathrm{C} 4: \mathrm{DBH}=60+70 \mathrm{~cm}$; and C5: $\mathrm{DBH} \geq 70 \mathrm{~cm}$ ).

Based on the distribution of diameters in previously determined amplitude classes, we fit probability density functions to estimate the future diametric structure of the forest stand. Several types of distribution can describe the diametric structure of trees. Among the most prominent in the literature, and used in this paper, are Log-Normal, Weibull- 3P, Gamma-2P, Burr-3P, and Johnson SB (e.g., Lima et al., 2014, Gorgoso-Varela \& Rojo-Alboreca, 2014, Lima et al., 2017). The parameters of these probability distribution functions were estimated using the maximum likelihood estimator (MLE). The fitted $f(x)$ and the packages and functions of the $\mathrm{R}$ statistical environment, version 3.4.3 are presented in Table 1. After fitting the functions, the estimated frequency curves were plotted on the frequency histograms.

Table 1. R statistical environment packages and probability density functions (PDFs) adjusted to describe the diameter distribution of Vouacapoua americana trees $(\mathrm{DBH} \geq 33 \mathrm{~cm}$ ) in a dense tropical forest in Anapu, Pará, Brazil.

\begin{tabular}{|c|c|c|c|c|}
\hline Name & pdf & Package & Function & Author \\
\hline Log-Normal & $\begin{array}{l}f(x)=\frac{1}{\mathrm{x} \sigma \sqrt{2 \pi}} \mathrm{e}^{\left[\frac{-1}{2}\left(\frac{\ln (x)-\mu}{\sigma}\right)^{2}\right]} \\
-\infty<\mathrm{x}<\infty ; \sigma>0 \mathrm{ex}>0\end{array}$ & fitdistrplus & $\begin{array}{l}\text { fitdist } \\
\text { dlnorm }\end{array}$ & $\begin{array}{c}\text { Delignette-Muller \& Dutang (2015) } \\
\text { R-base (R Core Team, 2017) }\end{array}$ \\
\hline Weibull (3P) & $\begin{array}{l}f(\mathrm{x})=\frac{\alpha}{\beta}\left(\frac{\mathrm{x}-\gamma}{\beta}\right)^{\alpha-1} \mathrm{e}^{\left[-\left(\frac{\mathrm{x}-\gamma}{\beta}\right)^{a}\right]} \\
\gamma \leq \mathrm{x}<\infty ; \alpha>0 ; \beta>0 ; \mathrm{x}>0\end{array}$ & $\begin{array}{l}\text { MASS } \\
\text { FAdist }\end{array}$ & dweibull3 & $\begin{array}{l}\text { Venables \& Ripley (2002) } \\
\text { Aucoin (2015) }\end{array}$ \\
\hline Gamma (2P) & $\begin{array}{c}f(x)=\frac{x^{\alpha-1}}{\beta^{-} \Gamma(\alpha)} e^{\left(\frac{-x}{\beta}\right)} \\
\alpha>0 ; \beta>0\end{array}$ & fitdistrplus & dgamma & Delignette-Muller \& Dutang (2015) \\
\hline
\end{tabular}

4 Area of Effective Management: Area of the Forest Management Unit (FMU) with potential for immediate or future harvest, excluding areas of permanent preservation, inaccessible areas, infrastructure and anthropized areas, under fallow or not, and legally unavailable areas. All definitions are taken from Normative Instruction No. 05 of September 10, 2015. 
Table 1. Continued...

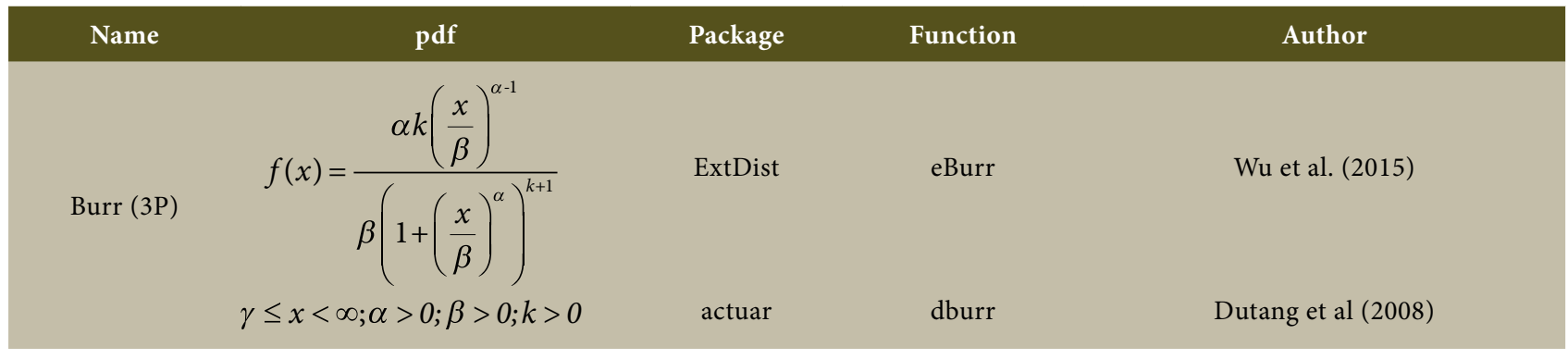

$$
\begin{aligned}
& f(x) \\
& \text { Johnson SB }=\frac{\delta}{\lambda \sqrt{2 \pi} z(1-z)} e^{\left[\frac{-1}{2}\left(\gamma+\delta \ln \left(\frac{z}{1-z}\right)\right)^{2}\right]} \\
& \text { SuppDists JohnsonFit or seed Wheeler (2016) } \\
& \zeta \leq x<\zeta+\lambda ; \delta>0 ; \lambda>0 \quad \begin{array}{ccc}
\text { SuppDists ou } & \text { dJohnson ou } \\
\text { ExtDist } & \text { dJohnsonSB }
\end{array}
\end{aligned}
$$

Log-Normal: $x=$ value of random variable (center of diameter class, $\mathrm{cm}$ ); $\mu=$ arithmetic mean (log scale) of random variable diameter, $\mathrm{cm} ; \sigma=$ standard deviation ( $\log$ scale) of random variable diameter, $\mathrm{cm} ; \pi=$ "pi" constant (3.1416); $\mathrm{e}=$ exponential; and $\mathrm{ln}=$ Napierian logarithm. Weibull (3P): $\mathrm{x}=$ value of random variable, $\mathrm{cm} ; \gamma=$ location parameter; $\beta=$ scale parameter; $\alpha=$ shape parameter; and $\mathrm{e}=$ exponential. Gamma $(\mathbf{2 P}): \mathrm{x}=$ value of random variable diameter, $\mathrm{cm} ; \alpha=$ shape parameter; $\beta=$ distribution scale parameter; $\Gamma=$ Gamma function; and $\mathrm{e}=$ exponential. Burr $(3 \mathbf{P}): \mathrm{x}=$ value of random variable (center of diameter class, $\mathrm{cm}$ ); $\mathrm{k}$ and $\alpha=$ shape parameter; and $\beta=$ scale parameter. Johnson SB: $\mathrm{x}=$ value of random variable, $\mathrm{cm} ; \gamma$ and $\delta=$ distribution shape parameters; $\zeta=$ location parameter; $\lambda=$ scale parameter; $\mathrm{e}=$ exponential; and $\mathrm{z}=(\mathrm{x}-\zeta) / \lambda$. For reference packages see supplementary document $\mathrm{S} 1$.

\subsection{Quality of adjustments}

After fitting, each of the PDFs was evaluated using the Kolmogorov-Smirnov (K-S) test, to determine whether the functions adhered to the observed diameter distribution (Péllico Netto et al., 2012).

The K-S test was used to compare the observed and estimated cumulative distributions of the adjusted functions, using the following formula: $d_{\text {cal }}=$, where $d_{\text {cal }}$ represents the calculated K-S statistic, which reflects the maximum difference between $F_{\mathrm{o}}(X)$ and $F_{\mathrm{e}}(X) ; F_{\mathrm{o}}(X)$ represents the observed cumulative frequency; $F_{\mathrm{e}}(X)$ represents the expected cumulative frequency (estimated by the model); and $n$ represents the number of observations (Orellana et al., 2014; Marangon et al., 2016; Cysneiros et al., 2017).

The null hypothesis $\left(\mathrm{H}_{0}\right)$ of the K-S test was that the observed diameters follow the tested distributions, and the alternative hypothesis $\left(\mathrm{H}_{1}\right)$ was that the observed diameters do not follow the tested distributions. When $d_{\text {cal }}$ was lower than the critical value $\left(d_{\text {crit. }}\right)$, the null hypothesis was not rejected, and we concluded that the adjusted function adhered to the real distribution data, at $99 \%$ level of probability.

The absolute and percentage standard error of estimation (SEest) were calculated using the following equations: SEest $=\sqrt{ }\left(\left(\Sigma\left[\left(\mathrm{y}_{\mathrm{i}}-\hat{y}_{\mathrm{i}}\right)^{2}\right]\right) /(\mathrm{n}-\mathrm{p})\right)$ and SEest $\%=($ SEest $/ \mathrm{y}) .100$, respectively, where SEest represents the standard error of estimation (absolute or percentage); $y_{\mathrm{i}}$ represents the number of trees observed in the $i$-th diameter class; $\hat{y}_{\mathrm{i}}$ represents the number of trees estimated in the $i$-th diameter class; $p$ represents the number of function parameters; $n$ represents the total number of trees; and $y$ represents arithmetic mean for data grouped into classes (Lana et al., 2013; Orellana et al., 2014). The arithmetic mean was used to calculate the SEest $\%$ of data grouped into classes. The PDFs were ranked according to the lowest $\mathrm{d}_{\text {cal. }}$ of the K-S test. Therefore, the PDF that presented the lowest lowest $\mathrm{d}_{\text {cal. }}$ was considered the one with the best adherence among all the distributions evaluated. In addition, estimated frequency curves were plotted for each function on the histogram of the observed frequencies, by diameter class (Machado et al., 2009; Binoti et al., 2014).

\subsection{Spatial autocorrelation}

The spatial autocorrelation of the V. americana trees was evaluated using the K function proposed by Ripley (1976) and the global Moran's index, using the geographic coordinates of each plant in the APU-2015.

Ripley's K function was applied for univariate cases, the total APU-2015 population, and for samples represented by the classes $\mathrm{C} 1-\mathrm{C} 5$. Owing to the low representativeness of trees in the upper classes, individuals with DBH values of $\geq 70 \mathrm{~cm}$ were grouped so that the $\mathrm{K}$ function could still be used.

The null hypothesis $\left(\mathrm{H}_{0}\right)$ for the $\mathrm{K}$ function is that occurs Complete Spatial Randomness (CSR) (Scalon et al., 2012), that is, individuals present random spatial distribution. 
Thus, in order to evaluate the CSR, confidence bounds were constructed at $99 \%$ probability from 1000 Monte Carlo simulations. The relationships between pairs of occurrences were measured every $5 \mathrm{~m}$, up to a maximum distance of $1,500 \mathrm{~m}$.

Based on the simulations, denotative graphs of the spatial patterns were obtained. Machado et al. (2012) point out that the positive and the negative boundary lines identify the CSR trust envelope. In addition, Capretz et al. (2012) state that the occurrence of values within the bounds indicates a random spatial pattern. Otherwise, when the $\mathrm{k}$ values are either above or below the envelope limits, the $\mathrm{H}_{0}$ should be rejected and the alternative hypothesis of an aggregate pattern should be accepted.

The global Moran's index comprises values that vary from -1 to +1 (Silva et al., 2017). Values between 0 and +1 indicate positive spatial corrections, whereas those between -1 and 0 indicate negative spatial correlations, and null values (zero) indicate a lack of spatial autocorrelation. The global Moran's index is a statistical test in which the null hypothesis express spatial independence $\left(\mathrm{H}_{0}: \mathrm{I}=0\right.$ vs. $\left.\mathrm{H}_{1}: \mathrm{I} \neq 0\right)$ (Dalposso et al., 2013).

\subsection{Harvest intensity scenarios}

The V. americana harvest scenarios were established under the hypothetical assumption of legal access to the species. Prior to analyzing the harvest intensity scenarios, the V. americana trees were categorized according to the technical criteria of SEMAS-PA and current forest legislation (Resolution No. 406, of February 2, 2009): i) Remaining with Future Harvest Potential (RFHP; DBH $<50 \mathrm{~cm}$, located in the AHA); ii) Harvest Potential (HP; $50 \mathrm{~cm} \leq \mathrm{DBH}<80 \mathrm{~cm}$, located in the AHA, with stem quality type 1 or 2); iii) Protected by Law (PL; located in permanent preservation areas); iv) Remaining with Non-commercial Stem (RNS; DBH $\geq 50 \mathrm{~cm}$, located in the AHA, with stem quality type 3 or 4 , that is, crooked and without commercial value); v) Remaining in Anthropized Area (RAA; located in the AA); and vi) Parent Trees (PT; exhibiting desirable phenotypic features or not found in any other category). All trees with DBH values of $\geq 80 \mathrm{~cm}$ were preserved, owing to their rarity. Then, the effects of hypothetical sustainable Vouacapoua americana harvest on the diameter structure of the species were explored, under three harvest intensity scenarios $(50,70$, and $80 \%)$. For this purpose, the function that best fit the original diameter structure was adjusted to the remaining diameter structure under each harvest scenario.

The scenarios were assessed under a conservative maintenance criterion (i.e., maintaining $15 \%$ of harvestable Vouacapoua americana trees in the AHA of the APU). The permanence criterion of a tree in the area, addressed by the Normative Instruction No. 01 from February 2015, is based on the sustainable management of vulnerable tree species according to the Official National List of Endangered Flora Species (Brasil, 2014).

Scenario 1 (Sc1): removal of $\sim 50 \%$ of harvestable trees, with the same harvest intensity within each FMU.

Scenario 2 (Sc2): removal of $\sim 70 \%$ of harvestable trees, with the same harvest intensity within each FMU.

Scenario 3 (Sc3): removal of $\sim 80 \%$ of harvestable trees, with the same harvest intensity within each FMU.

For each scenario, the createDataPartition function of the caret package in $\mathrm{R}$, version 3.4.3, was used to select from among harvestable trees (Kuhn, 2008), with FMU as the base of stratification. All data and R scripts are available as additional files.

\section{RESULTS AND DISCUSSION}

\subsection{Exploratory analysis}

Descriptive statistics for two dendrometric variables that were measured for the pre-harvest forest inventory (forest inventory at 100\%) of APU-2015 (545.27 hectares), from which an area of 440.87 hectares was effectively managed for other species, except Vouacapoua americana (Table 2). A total of 2,400 V. americana specimens were identified in the APU-2015 (4.40 ind.ha ${ }^{-1}$ ). The DBH of the trees ranged from 33.42 to $127.32 \mathrm{~cm}$, with an interquartile range of $15.92 \mathrm{~cm}$, which indicated that $50 \%$ of the diameters were between $44.56\left(\mathrm{Q}_{1}\right)$ and $60.48 \mathrm{~cm}\left(\mathrm{Q}_{3}\right)$. Variation of DBH was relatively low (19-26\%), especially for being an uneven-aged forest stand, and indicated a reasonably homogeneous data set.

Fisher's measure of skewness $\left(g_{1}\right)$ for DBH ranged from 0.51 to 1.78 in the forest management units, indicating positive skewness $\left(g_{1}>0\right)$, with the longest tail to the right. Fisher's measure of flatness $\left(\mathrm{g}_{2}\right)$ for DBH ranged from -0.20 to 5.69 in the assessment units, indicating a leptokurtic curve $\left(\mathrm{g}_{2}>0\right)$, that was more elongated than the normal distribution curve (0.263). Only FMU 2 yielded a platykurtic distribution $\left(\mathrm{g}_{2}<0\right)$, with a degree of flatness that was smaller than the Gauss curve.

Of all the trees inventoried, 1,909 were in the AHA (4.33 trees.ha ${ }^{-1}$ ). The initial inventory ${ }^{5}$ of each FMU in the AHA ranged from 0.0215 to $0.0494 \mathrm{~m}^{3} \cdot \mathrm{ha}^{-1}$, with an overall mean of $0.0265 \mathrm{~m}^{3} \cdot \mathrm{ha}^{-1}$ and a total volume of $3,885.46 \mathrm{~m}^{3}$. Descriptive statistics for the height (h), basal area $\left(\mathrm{m}^{2} \cdot \mathrm{ha}^{-1}\right)$, and volume $\left(\mathrm{m}^{3}\right)$ of trees in each FMU and in the entire APU-2015 are not included in the text, but they are important to better understand of Vouacapoua americana population structure in the forest (Table S2). 
Table 2. Descriptive statistics and initial stock in the actual harvest area of Vouacapoua americana trees (DBH $\geq 33 \mathrm{~cm})$ in the 2015 Annual Production Unit of Anapu, Pará, Brazil.

\begin{tabular}{|c|c|c|c|c|c|c|c|c|c|c|c|}
\hline & $\mathbf{n}$ & Mean & $\mathbf{Q}_{0.25}$ & Md & $\mathbf{Q}_{0.75}$ & Sd & $\mathrm{g}_{1}$ & $\mathrm{~g}_{2}$ & Min. & Max. & IQR \\
\hline \multicolumn{12}{|c|}{ Diameter $(\mathbf{c m})$} \\
\hline FMU-1 & 317 & 54.11 & 45.20 & 50.93 & 63.66 & 11.99 & 1.29 & 3.87 & 33.42 & 117.77 & 18.46 \\
\hline FMU-2 & 336 & 56.73 & 47.03 & 54.91 & 65.25 & 12.67 & 0.51 & -0.20 & 35.01 & 98.68 & 18.22 \\
\hline FMU-3 & 641 & 56.66 & 46.15 & 55.70 & 65.57 & 13.10 & 0.61 & 0.40 & 34.06 & 114.27 & 19.42 \\
\hline FMU-4 & 531 & 51.64 & 42.97 & 48.70 & 57.30 & 13.08 & 1.78 & 5.69 & 35.01 & 127.32 & 14.32 \\
\hline FMU-5 & 156 & 47.13 & 39.39 & 45.52 & 51.57 & 9.15 & 0.85 & 0.43 & 35.01 & 76.39 & 12.18 \\
\hline FMU-6 & 419 & 49.82 & 42.34 & 48.38 & 55.70 & 9.92 & 1.10 & 2.36 & 35.01 & 103.13 & 13.37 \\
\hline APU-2015 & 2,400 & 53.41 & 44.56 & 50.93 & 60.48 & 12.55 & 1.08 & 2.16 & 33.42 & 127.32 & 15.92 \\
\hline \multicolumn{12}{|c|}{ Initial volume in AHA $\left(\mathrm{m}^{3} \cdot \mathrm{ha}^{-1}\right)^{*}$} \\
\hline FMU-1 & 241 & 0.0266 & 0.0154 & 0.0215 & 0.0332 & 0.0175 & 3.2501 & 17.3196 & 0.0066 & 0.1495 & 0.0178 \\
\hline FMU-2 & 239 & 0.0279 & 0.0171 & 0.0249 & 0.0360 & 0.0141 & 0.8623 & 0.3271 & 0.0067 & 0.0747 & 0.0188 \\
\hline FMU-3 & 537 & 0.0248 & 0.0139 & 0.0214 & 0.0325 & 0.0143 & 1.7992 & 6.4770 & 0.0047 & 0.1243 & 0.0186 \\
\hline FMU-4 & 393 & 0.0265 & 0.0161 & 0.0217 & 0.0312 & 0.0183 & 4.2373 & 28.3695 & 0.0075 & 0.1868 & 0.0151 \\
\hline FMU-5 & 110 & 0.0494 & 0.0318 & 0.0415 & 0.0570 & 0.0253 & 1.5084 & 2.1431 & 0.0134 & 0.1368 & 0.0252 \\
\hline FMU-6 & 389 & 0.0215 & 0.0140 & 0.0187 & 0.0268 & 0.0108 & 1.8269 & 5.4289 & 0.0069 & 0.0896 & 0.0128 \\
\hline APU-2015 & 1,909 & 0.0265 & 0.0154 & 0.0223 & 0.033 & 0.0169 & 2.8527 & 15.0651 & 0.0047 & 0.1868 & 0.0177 \\
\hline
\end{tabular}

$\mathrm{n}=$ number of trees; $\mathrm{Q}_{0.25}=$ first quartile; $\mathrm{Md}=$ median; $\mathrm{Q}_{0.75}=$ third quartile; $\mathrm{Sd}=$ standard deviation; $\mathrm{g}_{1}=$ skewness; $\mathrm{g}_{2}=$ Kurtosis; Min. $=$ minimum; Max. = maximum; $\mathrm{IQR}=$ interquartile range; $\mathrm{FMU}=$ forest management units; and $\mathrm{APU}=$ Annual Production Unit. ${ }^{*}$ commercial volume of trees calculated using the form factor 0.7 (Pará 2015), through the formula $\mathrm{v}_{\mathrm{i}}=0.7\left[\left(\pi D B H^{2} / 4\right) h\right]$.

\subsection{Probability density functions (PDFs)}

The diametric distribution obtained from all inventoried individuals Vouacapoua americana population (UPA-2015) proved that most of the trees are in the diametric classes of $40+50 \mathrm{~cm}(\mathrm{C} 2)$ and $50+60 \mathrm{~cm}(\mathrm{C} 3)$, covering $59.96 \%$ of the total number of inventoried individuals. Similarly, the study of the diametric structure by UT also showed a tendency towards a higher concentration of individuals in classes $\mathrm{C} 2$ and $\mathrm{C} 3$, with accumulated percentages that varied between $24.80 \%$ (UT3) and $38.90 \%$ (UT6). The distribution of trees among the diameter classes was relatively similar among the FMUs, as long as the diameter categories were separated by $10 \mathrm{~cm}$. However, the frequency histograms of FMU 3 and FMU 5 were slightly different than those of the other FMUs. More specifically, in the FMU 3, a greater number of trees was placed in $\mathrm{C} 3$ than in $\mathrm{C} 2$, and in the FMU 5, a smaller number of trees were placed in $\mathrm{C} 3$ than in $\mathrm{C} 1$.

There was a noticeable reduction of the number of individuals per class as the diameter of the classes increased, which indicates that large individuals $(\mathrm{DBH}>80 \mathrm{~cm})$ were rare. In fact, less than $3 \%$ of the total inventoried individuals had DBH measurements $>80 \mathrm{~cm}$, and within FMUs, the percentage ranged from 0 (FMU 5) to $4 \%$ (FMU 3). Therefore, in a hypothetical scenario of Vouacapoua americana management, focused on its conservation, low-density diameter classes should be protected from harvest.

In most cases, we were unable to reject the null hypothesis ( $\mathrm{p}$-value $>0.01$ ) of the K-S, which indicated that the adjusted PDFs adhered to the original diameter distribution. However, for the individual FMUs, ranking the K-S and SEest $\%$ values revealed that other PDFs better fit the distributions data (Table 3). 
Table 3. Estimated parameters of probability density functions and Kolmogorov-Smirnov adherence values for the entire 2015 Annual Production Unit and for each of six working units.

\begin{tabular}{|c|c|c|c|c|c|c|c|c|c|c|c|c|c|c|}
\hline \multirow{3}{*}{ Functions } & \multicolumn{9}{|c|}{ ESTIMATED PARAMETERS } & \multirow{2}{*}{\multicolumn{3}{|c|}{$K-S$}} & \multirow{2}{*}{\multicolumn{2}{|c|}{ SEest }} \\
\hline & \multicolumn{9}{|c|}{ Annual Production Unit (APU-2015) } & & & & & \\
\hline & $\mathbf{k}$ & $\alpha$ & $\beta$ & $\gamma$ & $\delta$ & $\xi$ & $\lambda$ & $\sigma$ & $\mu$ & $\mathbf{d}_{\text {cal. }}$ & $\mathbf{d}_{\text {crit. }}$ & $\mathbf{R}$ & $\%$ & $\mathbf{R}$ \\
\hline Log-Normal & - & - & - & - & - & - & - & 0.223 & 3.952 & $0.0308^{\mathrm{ns}}$ & \multirow{5}{*}{0.033} & 3 & 15.13 & 3 \\
\hline Weibull 3P & - & 1.604 & 23.039 & 33.576 & - & - & - & - & - & $0.0159^{\mathrm{ns}}$ & & 2 & 1.77 & 1 \\
\hline Gamma (2P) & - & 19.743 & 0.369 & - & - & - & - & - & - & $0.0501^{*}$ & & - & 20.68 & 4 \\
\hline Burr (3P) & 0.693 & 8.979 & 48.241 & - & - & - & - & - & - & $0.0397^{*}$ & & - & 29.06 & 5 \\
\hline Johnson SB & - & - & - & 1.381 & 1.608 & 28.708 & 94.84 & - & - & $0.0158^{\mathrm{ns}}$ & & 1 & 4.28 & 2 \\
\hline \multicolumn{15}{|c|}{ FMU-1 } \\
\hline Log-Normal & - & - & - & - & - & - & - & 0.208 & 3.969 & $0.0381^{\mathrm{ns}}$ & \multirow{5}{*}{0.091} & 2 & 3.97 & 3 \\
\hline Weibull 3P & - & 1.830 & 23.678 & 33.070 & - & - & - & - & - & $0.0229^{\mathrm{ns}}$ & & 1 & 1.55 & 1 \\
\hline Gamma 2P & - & 22.515 & 0.416 & - & - & - & - & - & - & $0.0527^{\mathrm{ns}}$ & & 3 & 5.33 & 4 \\
\hline Burr (3P) & 0.719 & 9.515 & 49.629 & - & - & - & - & - & - & $0.0537^{\mathrm{ns}}$ & & 4 & 5.63 & 5 \\
\hline Johnson SB & - & - & - & 1.521 & 2.475 & 29.018 & 133.576 & - & - & $0.0911^{\mathrm{ns}}$ & & 5 & 2.37 & 2 \\
\hline \multicolumn{15}{|c|}{ FMU-2 } \\
\hline Log-Normal & - & - & - & - & - & - & - & 0.221 & 4.014 & $0.0559^{\mathrm{ns}}$ & \multirow{5}{*}{0.089} & 3 & 5.97 & 3 \\
\hline Weibull 3P & - & 1.925 & 26.465 & 33.237 & - & - & - & - & - & $0.0476^{\mathrm{ns}}$ & & 1 & 3.64 & 1 \\
\hline Gamma 2P & - & 20.570 & 0.363 & - & - & - & - & - & - & $0.0541^{\mathrm{ns}}$ & & 2 & 6.65 & 4 \\
\hline Burr (3P) & 1.376 & 6.937 & 59.216 & - & - & - & - & - & - & $0.0601^{\mathrm{ns}}$ & & 5 & 9.49 & 5 \\
\hline Johnson SB & - & - & - & 1.572 & 1.786 & 22.724 & 110.405 & - & - & $0.0562^{\mathrm{ns}}$ & & 4 & 4.12 & 2 \\
\hline \multicolumn{15}{|c|}{ FMU-3 } \\
\hline Log-Normal & - & - & - & - & - & - & - & 0.228 & 4.011 & $0.0330^{\mathrm{ns}}$ & \multirow{5}{*}{0.064} & 3 & 5.20 & 4 \\
\hline Weibull 3P & - & 2.202 & 32.608 & 28.366 & - & - & - & - & - & $0.0156^{\mathrm{ns}}$ & & 1 & 0.74 & 1 \\
\hline Gamma 2P & - & 19.316 & 0.341 & - & - & - & - & - & - & $0.0292^{\mathrm{ns}}$ & & 2 & 3.98 & 3 \\
\hline Burr (3P) & 1.390 & 6.757 & 59.311 & - & - & - & - & - & - & $0.0431^{\mathrm{ns}}$ & & 5 & 7.72 & 5 \\
\hline Johnson SB & - & - & - & 0.573 & 1.133 & 29.336 & 69.06 & - & - & $0.0350^{\mathrm{ns}}$ & & 4 & 0.93 & 2 \\
\hline \multicolumn{15}{|c|}{ FMU-4 } \\
\hline Log-Normal & - & - & - & - & - & - & - & 0.227 & 3.917 & $0.0577^{\mathrm{ns}}$ & \multirow{5}{*}{0.071} & 3 & 4.41 & 3 \\
\hline Weibull 3P & - & 1.404 & 18.821 & 34.494 & - & - & - & - & - & $0.0203^{\mathrm{ns}}$ & & 2 & 0.28 & 1 \\
\hline Gamma 2P & - & 18.417 & 0.357 & - & - & - & - & - & - & $0.0829^{*}$ & & - & 7.63 & 4 \\
\hline Burr (3P) & 0.539 & 10.362 & 44.664 & - & - & - & - & - & - & $0.0580^{\mathrm{ns}}$ & & 4 & 8.32 & 5 \\
\hline Johnson SB & - & - & - & 0 & 2.823 & 17.974 & 30.91 & - & - & $0.0188^{\mathrm{ns}}$ & & 1 & 0.90 & 2 \\
\hline \multicolumn{15}{|c|}{ FMU-5 } \\
\hline Log-Normal & - & - & - & - & - & - & - & 0.185 & 3.835 & $0.0729^{\mathrm{ns}}$ & \multirow{5}{*}{0.130} & 2 & 4.88 & 4 \\
\hline Weibull 3P & - & 1.900 & 21.279 & 28.540 & - & - & - & - & - & $0.0199^{\mathrm{ns}}$ & & 1 & 0.09 & 1 \\
\hline Gamma 2P & - & 28.556 & 0.606 & - & - & - & - & - & - & $0.0766^{\mathrm{ns}}$ & & 3 & 4.63 & 3 \\
\hline Burr (3P) & 0.598 & 11.529 & 42.479 & - & - & - & - & - & - & $0.0897^{\mathrm{ns}}$ & & 4 & 10.64 & 5 \\
\hline Johnson SB & - & - & - & 0.939 & 1.026 & 31.001 & 49.05 & - & - & $0.0926^{\mathrm{ns}}$ & & 5 & 2.01 & 2 \\
\hline \multicolumn{15}{|c|}{ FMU-6 } \\
\hline Log-Normal & - & - & - & - & - & - & - & 0.189 & 3.889 & $0.0318^{\mathrm{ns}}$ & \multirow{5}{*}{0.079} & 4 & 2.06 & 3 \\
\hline Weibull 3P & - & 2.281 & 23.410 & 29.030 & - & - & - & - & - & $0.0195^{\mathrm{ns}}$ & & 1 & 0.12 & 1 \\
\hline Gamma 2P & - & 27.393 & 0.549 & - & - & - & - & - & - & $0.0277^{\mathrm{ns}}$ & & 3 & 1.18 & 2 \\
\hline Burr (3P) & 0.685 & 10.667 & 45.766 & - & - & - & - & - & - & $0.0498^{\mathrm{ns}}$ & & 5 & 11.74 & 5 \\
\hline Johnson SB & - & - & - & 1.121 & 1.323 & 29.789 & 61.99 & - & - & $0.0222^{\mathrm{ns}}$ & & 2 & 2.13 & 4 \\
\hline
\end{tabular}

$\mathrm{k}$ and $\alpha=$ estimated distribution shape parameter; $\boldsymbol{\beta}=$ estimated scale parameter; $\gamma$ and $\delta=$ estimated distribution shape parameters; $\boldsymbol{\lambda}=$ estimated scale parameter; $\boldsymbol{\xi}=$ estimated location parameter; $\boldsymbol{\sigma}=$ standard deviation; $\boldsymbol{\mu}=$ arithmetic mean; $\mathrm{d}_{\mathrm{cal}}$ and $\mathrm{d}_{\text {crit }}=$ calculated and critical Kolmogorov-Smirnov values; ${ }^{*}=$ significant at the $99 \%$ level, indicating no adherence to the distribution; $n s=$ not significant, exhibiting adherence to the distribution $(\alpha=0.01)$; SEest $=$ standard error of estimation; and $\mathrm{R}=$ ranking. 
The Weibull (3P) PDF exhibited the best overall fit to the original data, yielding the smallest $d_{\text {cal. }}$ for FMU 1 , FMU 2, FMU 3, FMU 5, and FMU 6, although the Johnson SB PDF presented the best fit for the entire APU-2015 and FMU 4. The Weibull (3P) PDF was also superior to the other distributions in regard to SEest\%, with values that ranged from 0.09 (FMU 5) to 3.64\% (FMU 2) (Figure 2).
Although the Johnson SB PDF performed better than the Weibull (3P) PDF in the APU-2015 and FMU 4, it did not maintain its performance in the other FMUs, reaching the fourth or fifth position on the K-S ranking, with the exception of FMU 6. On the other hand, the Johnson SB PDF yielded small SEest\% values that ranged from 0.90 (FMU 4) to 4.28 (APU-2015).
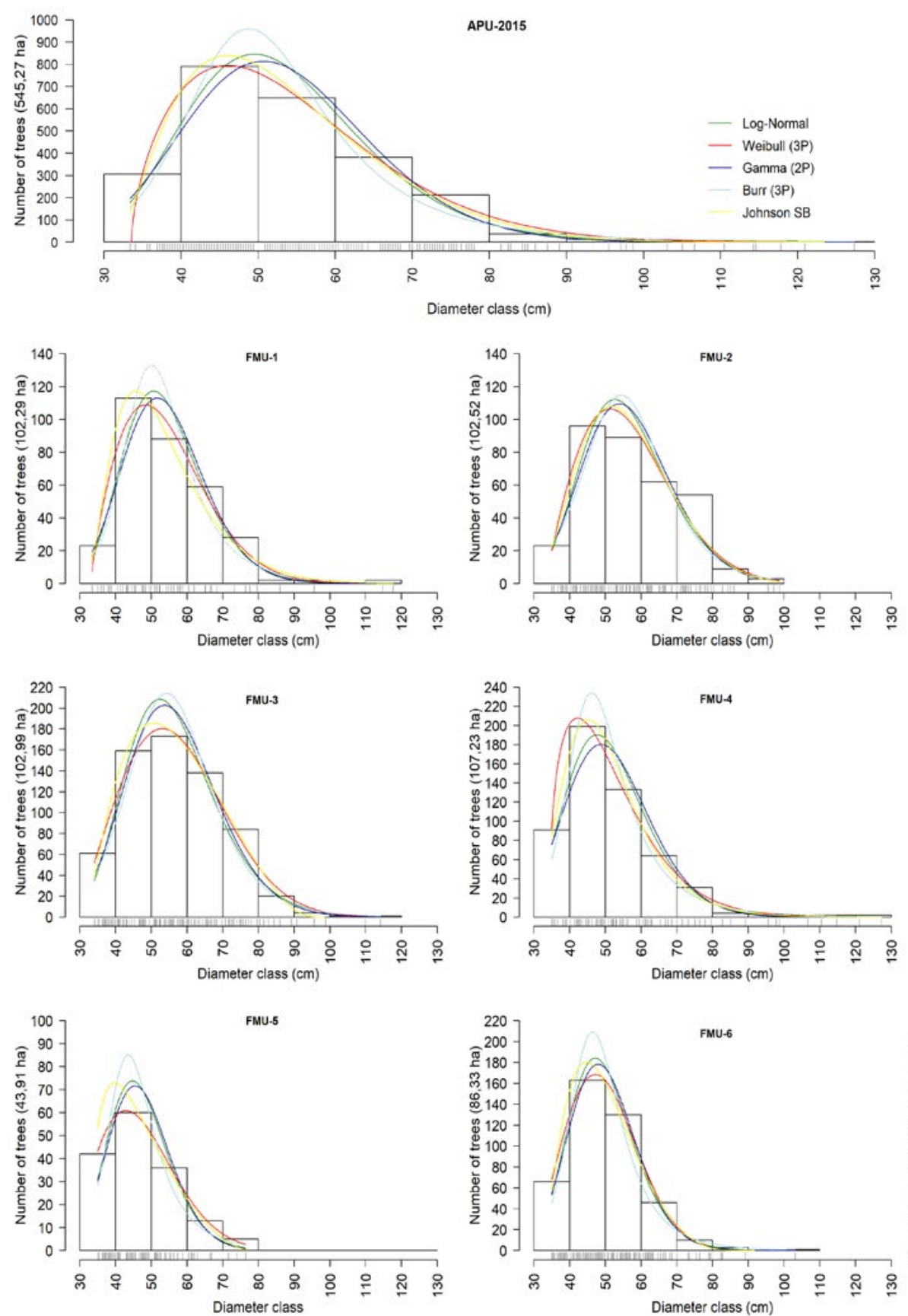

Figure 2. Frequency and adjusted probability density functions for the diameter structure of Vouacapoua americana in the entire 2015 Annual Production Unit of Anapu and in each of six forest management units. 
Interestingly, a smaller K-S value does not necessarily infer a smaller SEest $\%$ value. For instance, in situations where the Johnson SB PDF performed better than the Weibull (3P) $\mathrm{PDF}$, the standard errors of the functions estimate of absolute frequencies were higher than those of the Weibull (3P) PDF.

The Gamma (2P) PDF was unable to adhere to the diameter distribution data of either the APU-2015 or FMU 4, and the Burr (3P) PDF was unsatisfactory for modeling the diameter structure of the APU-2015. In general, the Burr (3P) PDF exhibited the worst fit to the real distribution data, according to the K-S test and SEest\% values.

\subsection{Spatial distribution analysis}

The $V$. americana trees presented an aggregated spatial distribution, as indicated by the univariate Ripley K function.
The estimated $\mathrm{L}(\mathrm{s})$ in classes $\mathrm{C} 1$ and $\mathrm{C} 5$ yielded continuous aggregate patterns over the whole distance scale. The horizontal line $(L(s)=0)$ represents the reference for the confidence bounds (dashed line) at $99 \%$ probability, and the solid lines represent the adjustment obtained using the modified Ripley's K function, L(s) (Figure 3).

Spatial autocorrelation was also verified by the global Moran's index $(\mathrm{I}=0.191266, \mathrm{z}$-score $=14.221354$, p-value $=0.000)$, which confirmed a highly aggregated distribution at a $99 \%$ level of probability. Unique transition points were observed in the APU-2015, as well as in classes C2, C3, and C4, which exhibited changed spatial patterns. The estimation of K for the APU-2015 yielded increasing $\mathrm{L}(\mathrm{s})$ values up to $\sim 400 \mathrm{~m}$ and then a random pattern at $\sim 1,100 \mathrm{~m}$. In classes C2, C3, and C4, the estimated $\mathrm{L}(\mathrm{s})$ values increased up to the 400,400 , and $700 \mathrm{~m}$ distances, respectively, with transition points at 600,700 , and $1,200 \mathrm{~m}$.
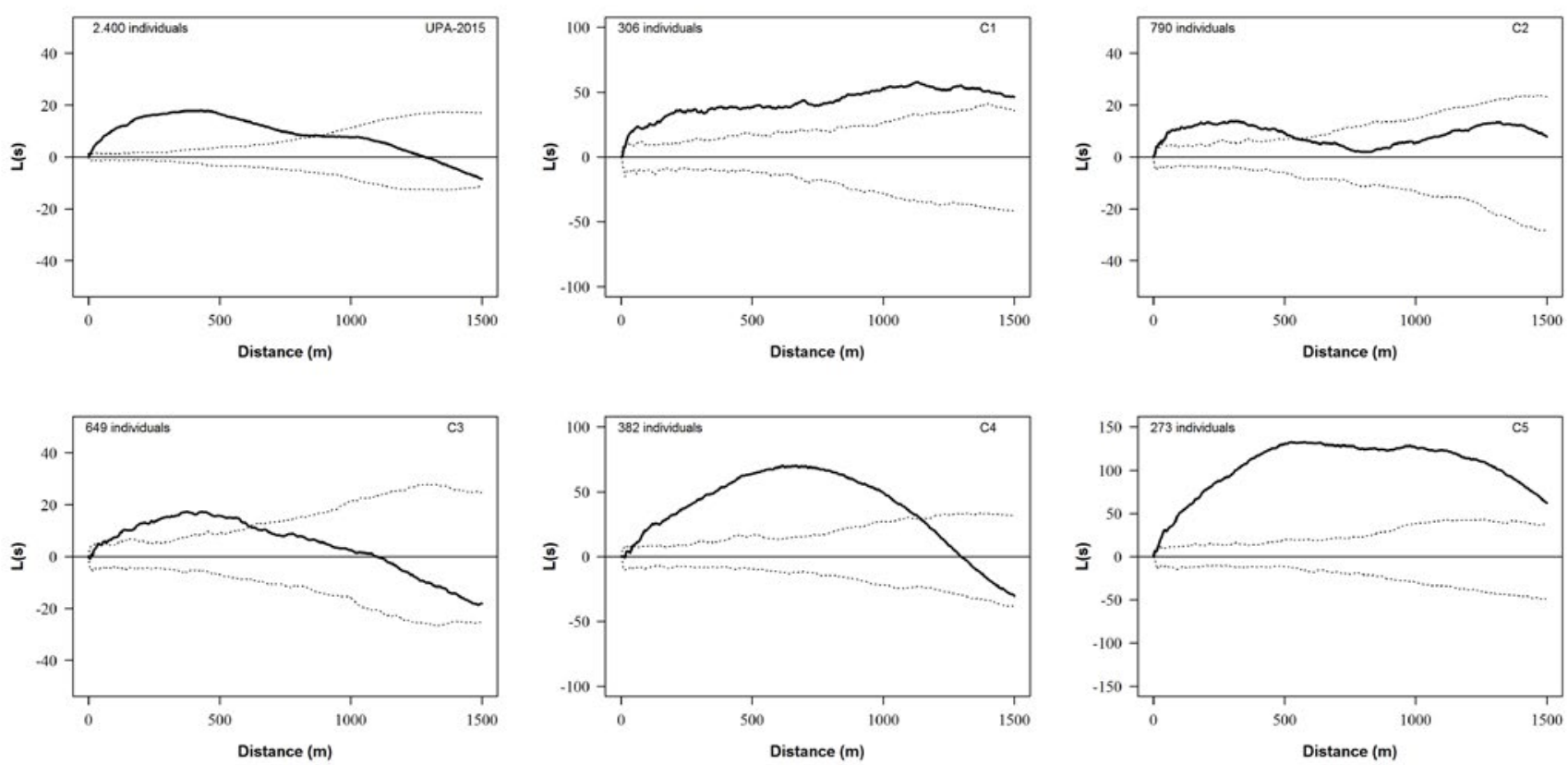

Figure 3. Estimated and transformed univariate Ripley K function values (estimated L) for Vouacapoua americana in the sampling area and diameter class. $\mathrm{C} 1: \mathrm{DBH}=30 \vdash 40 \mathrm{~cm} ; \mathrm{C} 2: \mathrm{DBH}=40 \vdash 50 \mathrm{~cm} ; \mathrm{C} 3: \mathrm{DBH}=50 \vdash 60 \mathrm{~cm} ; \mathrm{C} 4: \mathrm{DBH}=60 \vdash 70 \mathrm{~cm}$; and C5: $\mathrm{DBH} \geq 70 \mathrm{~cm}$.

Although there are differences in the estimate curves of Ripley's K function, the aggregate pattern is common in tropical forests, mostly due to the large number of conspecific trees within specific neighborhoods (Hubbell, 1979). Aggregation levels are mainly attributed to resource availability, microclimatic conditions, and reduced dispersion capacity (Haase, 1995; Grau, 2000). Capretz et al. (2012) noted that plants at different life stages have different needs and, as a result, exhibit different spatial patterns. In particular, the aggregated spatial distribution pattern of $V$. americana over short distances could be attributed to its barochoric dispersion, in which seeds fall from parent trees and are generally disseminated short distances by small rodents (Santos \& Jardim, 2012).

\subsection{Harvest intensity scenarios}

From the 2,400 trees surveyed, 1,304 individuals with DBH values of $\geq 50.0 \mathrm{~cm}$ and only 855 with DBH values 
between 50 and $80 \mathrm{~cm}$ were classified under the "Harvest Potential" category, since they were located in the AHA and presented straight stems (commercially desirable) (Figure 4). In every scenario, $15 \%$ of the "Harvest Potential" trees (129 individuals) were maintained in the APU-2015 and the FMUs. Thus, scenarios 1, 2, and 3 involved the harvest of 428,600 , and 686 trees of the AHA, which corresponded to wood volumes of $15.0415,20.2033$, and $23.2470 \mathrm{~m}^{3} \cdot \mathrm{ha}^{-1}$, respectively. The Weibull (3P) PDF provided the best fit to the original diameter structure, thus it was able to describe the diameter distribution in the APU-2015 and FMUs after the simulated removal of 50 and $70 \%$ of Vouacapoua americana trees. However, the $80 \%$ scenario was considered too severe, since the Weibull (3P) PDF was unable to describe the remaining diameter structure, with the exception of FMU 5 and FMU 6 (Table S3 e S4).
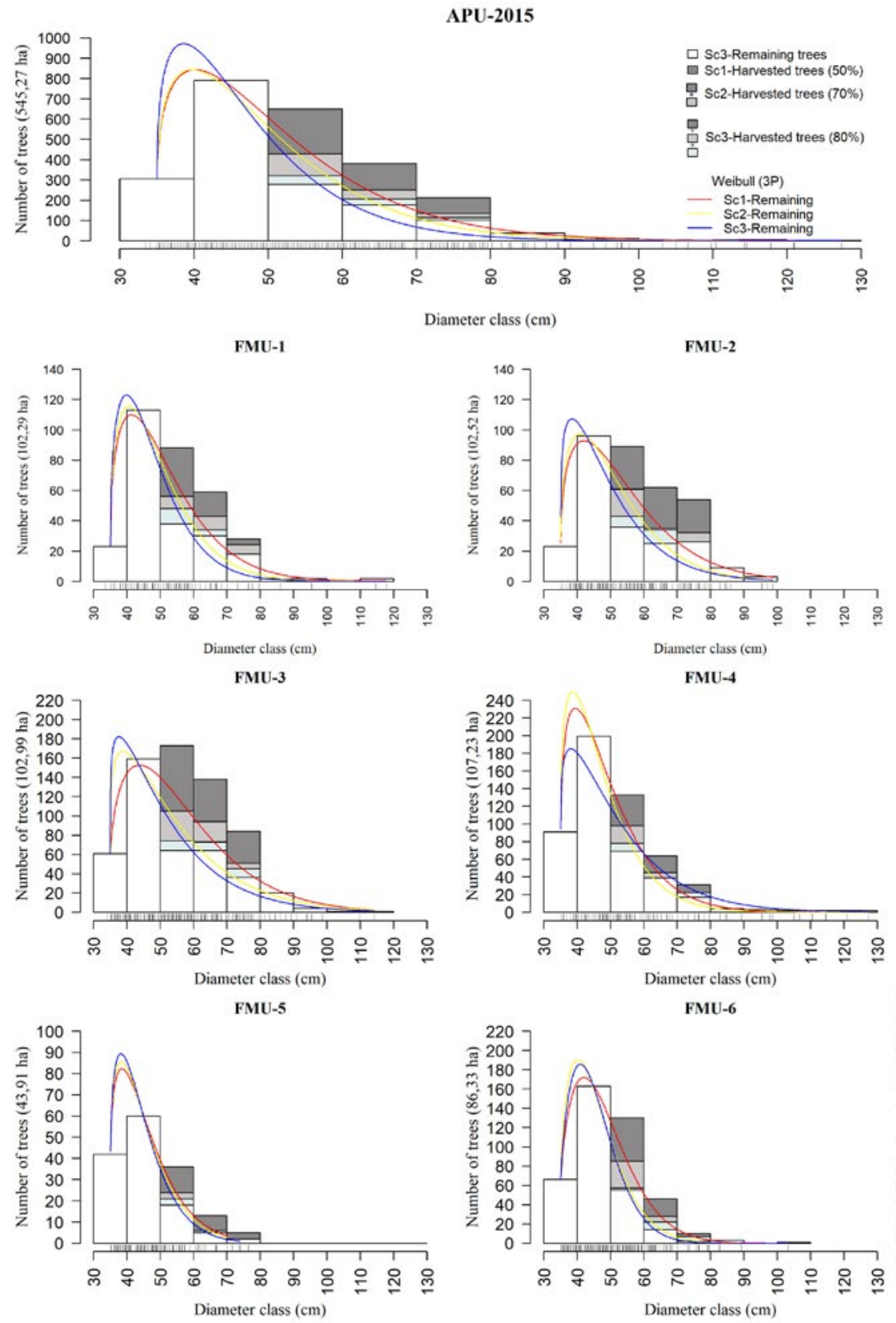

Figure 4. Harvest intensity scenarios (50, 70, and 80\%) for the 2015 Annual Production Unit and effort units, as well as their impact on the diameter structure of Vouacapoua americana in Anapu, Pará, Brazil. Sc1-, Sc2-, and Sc3-Remaining: trees remaining in scenarios 1, 2, and 3, respectively; Sc1-, Sc2-, and Sc3-Harvested: trees hypothetically harvested in scenarios 1, 2, and 3, respectively. 
Under every scenario, the hypothetical volume harvested per ha in the AHA can be considered high when accounting for the volume restriction applied by SEMAS-PA, which only authorizes the harvest of $6 \mathrm{~m}^{3} \cdot \mathrm{ha}^{-1}$ per species. Conversely, the results of the present study confirm, even if indirectly, that lower harvest intensities maintain the original diameter distribution characteristics of V. americana and, therefore, can be safely put into practice.

\section{CONCLUSIONS}

The $V$. americana trees presented an aggregated spatial distribution. The remaining diameter structures of the 50 and $70 \%$ harvest scenarios suggest that the effects of harvest on diameter distribution and the occurrence of rare classes would be minimal and cause little harm to the original diameter structure of the population. However, other natural factors, as population size, dynamics, geographic distribution, should be used as indicators for forest management and conservation of the specie.

\section{SUBMISSION STATUS}

Received: 04 Apr. 2019

Accepted: 16 Sep. 2020

Associate editor: Emanuel José Gomes de Araújo

\section{CORRESPONDENCE TO}

\section{Deivison Venicio Souza}

Universidade Federal do Pará (UFPA), Faculdade de Engenharia Florestal, Rua Coronel José Porfírio, 2515, CEP 68371-040, Altamira, PA, Brasil e-mail: deivisonvs@ufpa.br

\section{REFERENCES}

Binoti DHB, Binoti MLMS, Leite HG, Cordeiro MA, Santos SC. Funções densidade de probabilidade para descrição da distribuição diamétrica de povoamentos de Acacia mangium. Revista Brasileira de Ciências Agrárias, v. 9, n. 4, p. 583-589, 2014.

Brasil. Portaria MMA no 443, de 17 de dezembro de 2014. Reconhece como espécies da flora brasileira ameaçadas de extinção aquelas constantes da "Lista Nacional Oficial de Espécies da Flora Ameaçadas de Extinção”. Diário Oficial da República Federativa do Brasil, Brasília, DF (2014 dez. 18).

Capretz RL, Batista JLF, Sotomayor JFM, Cunha CR, Nicoletti MF, Rodrigues RR. Padrão espacial de quatro formações florestais do estado de São Paulo, através da função K de Ripley. Ciência Florestal 2012; 7(3): 551-565.

Cysneiros VC, Amorim TA, Mendonça Júnior JO, Gaui TD, Moraes JCR, Braz DM, Machado SA. Distribuição diamétrica de espécies da Floresta Ombrófila Densa no Sul do Estado do Rio de Janeiro. Pesquisa Florestal Brasileira 2017; 37(89): 1-10.
Condit R, Ashton PS, Baker P, Bunyavejchewin S, Gunatilleke S, Gunatilleke $\mathrm{N}$ et al. Spatial patterns in the distribution of tropical tree species. Science 2000; 288(5470): 1414-1418.

Dalposso GH, Uribe-opazo MA, Mercante E, Lamparelli RAC. Spatial autocorrelation of NDVI and GVI indices derived from landsat/TM images for soybean crops in the Western of the State of Paraná in 2004/2005 crop season. Engenharia Agrícola 2013; 33(3): 525-537.

Delignette-Muller ML, Dutang C. Fitdistrplus: An R package for fitting distributions. Journal of Statistical Software 2015; 64(4): 1-34. Available from: http://www.jstatsoft.org/v64/i04/.

Dutang C, Goulet V, Pigeon M. actuar: An R package for actuarial science. Journal of Statistical Software 2008; 25(7): 1-37. Available from: http://www.jstatsoft.org/v25/i07.

Feeley KJ, Silman MR. Extinction Risks of Amazonian Plant Species. Proceedings of the National Academy of Sciences of the United States of America-PNAS 2009; 106(30): 12382-12387.

Forzza RC, Baumgratz JFA, Bicudo CEM, Carvalho JR. AA, Costa A, Costa DP et al. Catálogo das Plantas e Fungos do Brasil. Rio de Janeiro: Andrea Jakobsson Estúdio: Instituto de Pesquisas Jardim Botânico do Rio de Janeiro; 2010.

Forzza RC, Baumgratz JFA, Bicudo CEM, Carvalho JR. AA, Costa A, Costa DP et al. New Brazilian Floristic List Highlights Conservation Challenges. BioScience 2012; 62(1): 39-45.

Gorgoso-Varela JJ, Rojo-Alboreca A. Use of Gumbel and Weibull functions to model extreme values of diameter distributions in forest stands. Annals of forest science 2014; 71(7): 741-750.

Grau H. Regeneration patterns of Cedrela lilloi (Meliaceae) in Northwestern Argentina subtropical montane forests. Journal of Tropical Ecology 2000; 16: 227-242.

Haase P. Spatial pattern analysis in ecology based on Ripley's $\mathrm{k}$ function: introduction and methods of edge correction. Journal of Vegetation Science 1995; 6: 575-582.

Hubbell SP. Tree dispersion, abundance and diversity in a tropical dry forest. Science 1979; 203: 1299-1309.

John R, Dattaraja HS, Suresh HS, Sukumar R. Density-dependence in common tree species in a tropical dry forest in Mudumalai, Southern India. Journal of Vegetation Science 2002; 13: 45-56.

Kuhn M. Building predictive models in $\mathrm{R}$ using the caret package. Journal of statistical software 2008; 28(5): 1-26.

Lana MD, Lins CF, Brandão S, Netto SP, Marangon LC, Retslaff FAS. Distribuição diamétrica de Escheweilera ovata em um fragmento de Floresta Ombrófila Densa-Igarassu, PE. Floresta 2013; 43(1): 59-68.

Lima, RAF, Batista, JLF, Prado, PI. Modeling tree diameter distributions in natural forests: an evaluation of 10 statistical models. Forest Science 2014; 61(2): 320-327.

Lima, RB, Bufalino, L, Alves Junior, FT, SILVA, JAD, Ferreira, RL. Diameter distribution in a Brazilian tropical dry forest domain: predictions for the stand and species. Anais da Academia Brasileira de Ciências 2017; 89(2):1189-1203.

Machado SA, Augustynczik ALD, Nascimento RGM, Téo SJ, Miguel EP, Figura MA et al. Funções de distribuição diamétrica em um fragmento de Floresta Ombrófila Mista. Ciência Rural 2009; 39(8): 2428-2434. 
Machado SA, Santos AAP, Zamin NT, Nascimento RGM. Distribuição espacial de um fragmento de Floresta Ombrófila Mista Montana. Ciência Rural 2012; 42(6): 1013-1019.

Marangon GP, Ferreira RLC, Silva JAA, Schneider PR, Loureiro GH. Modelagem da Distribuição Diamétrica de Espécies Lenhosas da Caatinga, Semiárido Pernambucano. Ciência Florestal 2016; 26(3): 863-874.

Martinelli G, Moraes MA. Livro Vermelho da Flora do Brasil. 1rd ed. Instituto de Pesquisas Jardim Botânico do Rio de Janeiro, 2013.

Orellana E, Figueiredo Filho A, Péllico Netto S, Dias AN. Modelagem da distribuição diamétrica de espécies florestais em um fragmento de floresta ombrófila mista. Revista Árvore 2014; 38(2): 297-308.

Péllico Netto S, Orellana E, Stepka TF, Lima R, Figueiredo Filho A. Comportamento probabilístico dos raios das sextas árvores no método de Prodan e estimativas dos parâmetros dendrométricos para Araucaria angustifolia (Bertol.) Kuntze nativa. Scientia Forestalis 2012; 40: 517-524.

Porro R, Porro NSM, Menezes MC, Bartholdson Ö. Collective action and forest management: institutional challenges for the environmental agrarian reform in Anapu, Brazilian Amazon. International Forestry Review 2015; 17: 20-37.

Ripley BD. The second-order analysis of stationary point process. Journal of Applied Probability 1976; 13(2): 255-266.

Sanquetta CR, Behling A, Dalla Corte A P, Péllico Netto S, Rodrigues AL, Simon AA. A Model Based on Environmental Factors for Diameter Distribution in Black Wattle in Brazil. Plos One 2014; 9: e100093.

Santos CAN, Jardim FCS. Dinâmica da regeneração natural de Vouacapoua americana com diâmetro $<5 \mathrm{~cm}$, influenciada por clareiras, em Moju, Pará. Floresta 2012; 42(3): 495-508.

SEMAS-PA (2016) Extração e comércio de toras de madeira nativa por essência: 2016. URL http://monitoramento.sema.pa.gov.br/ sisflora/index.php/relatorios.

Scalon JD, Oliveira CAP, Mello JM. Análise espacial de um fragmento florestal baseada no Mosaico de Dirichlet. Revista Árvore 2012; 36(4): 733-740.

Silva AC, Higuchi P, Sobral MEG, Negrini M, Buzzi JR. F, Bento MA et al. Organização da comunidade e estrutura filogenética do componente arbóreo de um fragmento de floresta nebular no planalto Catarinense. Ciência Florestal 2017; 27(1): 129-141. 


\section{SUPPLEMENTARY MATERIAL}

The following online material is available for this article:

Supplementary S1 - Additional references.

Table S1 - Quantification of areas in the Annual Production Unit 2015 (APU-2015) in a dense tropical forest in Anapu, Pará, Brazil.

Table S2 - Descriptive statistics of height $(\mathrm{m})$, basal area $\left(\mathrm{m}^{2}\right.$.ha-1) and volume $\left(\mathrm{m}^{3}\right)$, by FMU and APU-2015, of the data set of Vouacapoua americana $(\mathrm{DBH} \geq 33 \mathrm{~cm})$, in a dense tropical forest in Anapu, Pará, Brazil.

Table S3 - Number of trees, basal area and simulated volume of exploitation and remaining in the harvest intensity scenarios, APU-2015 and each FMU, and conservative maintenance criterion (maintaining 15\% of harvestable Acapu trees in the AHA of the APU), in a dense tropical forest in Anapu, Pará, Brazil.

Table S4 - Estimate parameters and the values of the Kolmogorov-Smirnov adherence test. for the Weibull function (3P) for the remaining diametric structure of Vouacapoua americana after simulation of the harvest intensity scenarios in a dense tropical forest in Anapu. Pará. Brazil. 